\title{
Effect of Tillage Operations on Soil Moisture Contents in the Southern Guinea Savanna Ecological Zone of Nigeria
}

\author{
R. M. Olanrewaju1, A. S. Abubakar² \\ ${ }^{1}$ Department of Geography and Environmental Management, University of Ilorin, Ilorin, Nigeria \\ ${ }^{2}$ Department of Geography, Federal University of Technology, Minna, Nigeria \\ Email: rodamoji@gmail.com
}

Received 25 January 2015; accepted 10 February 2015; published 13 February 2015

Copyright (C 2015 by authors and Scientific Research Publishing Inc.

This work is licensed under the Creative Commons Attribution International License (CC BY).

http://creativecommons.org/licenses/by/4.0/

(c) (i) Open Access

\section{Abstract}

An experimental farm plot was set up at the National Centre for Agricultural Mechanization (NCAM), kilometer 12 Ilorin-Idofian Road to investigate the effect of various agronomic operations (mound, ridge and plough tillage) on soil moisture content of varying depth intervals of 0 - $15 \mathrm{~cm}$, $15-30 \mathrm{~cm}, 30-45 \mathrm{~cm}$ and $45-60 \mathrm{~cm}$ respectively. The experiment was conducted between year 2007 and 2009. Samples were taken on weekly basis from various depths using hand screw auger. The percentage moisture was determined by oven drying oil sample to a constant weight at the temperature of $105^{\circ} \mathrm{C}$. The difference between the initial weight and weight after oven drying was calculated and the percentage determined. Weekly data generated were grouped on monthly basis and the means calculated. Seasonal values were also calculated. ANOVA and the Post Hoc multiple comparison were employed to investigate variations in soil moisture content between tillage systems and within the four soil depths. The result showed mound tillage to be the driest and ridge was then wettest of all the tillage system considered. The difference between varying intervals of seach tillage became more pronounced between depth intervals of $0-15 \mathrm{~cm}$ and $15-30 \mathrm{~cm}$. Generally, the result of ANOVA indicates seasonal variation in soil moisture between the three tillage methods at all depths considered. Again the result of the Pos Hoc multiple comparison shows that variation in soil moisture content between the 3 tillage systems in wet and in dry season in not significant because the $p$ value $>0.05$. Suggestions were made on the way forward towards achieving a self sufficient food production status.

\section{Keywords}

Agronomic Operation, Soil Moisture, Soil Depth, Oven Drying 


\section{Introduction}

A wide gap exists between food production and population growth in Nigeria [1]. Some of the reasons for this gap emanate from poor yield that resulted from climatic vagaries [2]. For Nigeria to be self sufficient in food production, efforts should be geared towards closing up this gap. Some of such efforts include investigating the various tillage operations as they affect some fundamentals of crop productions such as soil moisture in a rain fed ecological environment.

Tillage, the physical manipulation of the soil for preparation of seed beds among others affects crop growth and yields by changing soil structure and moisture removal pattern over the growing season [3]. Crop water requirement represents the amount of water crops needed to grow and yield optimally [4]. Plant removes water from available soil moisture through its roots. The energy plant used to extract water from the soil according to [5] is termed matric potential and the symptoms of stress and depression displayed by plant (wilting) under a strong matric potential is known as matric effect.

The ability of plant to remove water from the soil is stressed when the soil moisture is low, saline or both. In any case, low soil moisture brings crop performance into crises level in various ways.

Plant root cannot easily take nutrients from the soil without water. It is the evaporation of the water taken by the plant root that keeps it at correct working temperature otherwise plants would gain heat, shrivel and die. Moisture supply has been described by [6] as the usual limiting factor of crop yield. For instance, water and carbon dioxide are important components of photosynthesis a process where plants manufacture their food (carbohydrate).

Besides, water stress brings about a reduction in leaf water pressure which often results into stomata closure. This has a lot of implications for the exchange of water and gases $\left(\mathrm{CO}_{2}\right.$ and $\left.\mathrm{O}_{2}\right)$ in and out of leaves (plant respiration) and on photosynthetic activities of plant as well. The wilting of plant consequent of low plant water drastically reduces the amount of leaf area exposed to sunlight for the process of photosynthesis. This present study is tailored to appraise the status of soil moisture at varying depth intervals among three tillage systems and established the tillage system(s) that is best suited for optimal crop yield in the southern guinea savanna ecological zone of Nigeria.

\section{Tillage Operations, Soil Moisture Content and Yield}

Tillage operations influence the available soil moisture and hence crop yield in diverse ways. [7] defined tillage as means of soil structure modification to favour agronomic process such as water infiltration among others. [8] examined the effect of four types of tillage operations on soil moistures and morphology and performance of 3 varietes of cotton in Golestan Province of Northern Iran. The results show that water storage capacity increases under no-till system. Low till cultivation leads to 695.8, 227.8 and $129.5 \mathrm{~kg} / \mathrm{ha}$ increase in yield compared to disk, chisel/disk and mold/disk treatment.

[6] as cited in [3] described soil moisture as the limiting factor of crop yield. This assertion has been confirmed by findings of [8]-[10], among others. [9] investigated the influence of soil moisture and phosphate levels on root growth of corn. The result shows soil moisture having greater influence on root hair growth of maize crop. [8] performed a field experiment on the effect of different soil moisture conservation practices on evaporation and growth of young tea plant (camellia sinensis). The result suggest maximum plant of $6.16 \mathrm{~m}$ under T2 may be linked with conservation of high moisture content and more organic matter while the minimum height of $3.55 \mathrm{~m}$ observed in T1 may not be unconnected with less availability of moisture content in the soil. [10] studied the effect of soil moisture stress on the growth of Corcliorus olitorius L. in green house during summer at Tokyo, Japan. The result showed smaller growth in light moisture stress $(60 \%-50 \%)$ and acute moisture stress ( $40 \%-30 \%)$ comparing to that of field capacity soil moisture. It was reported that pants were stunted under soil stress condition.

\section{The Study Area}

The map of the study area is shown in Figure 1. A research farm was set up at Nigerian Centre for Agricultural Mechanization (NCAM) located at Kilometer 12 Idofian-Ilorin Road, Kwara State Nigeria.

\section{Method of Study}

Three farm plots measured $13 \mathrm{~m}$ by $10 \mathrm{~m}$ each designated ABC were prepared using different agronomic prac- 


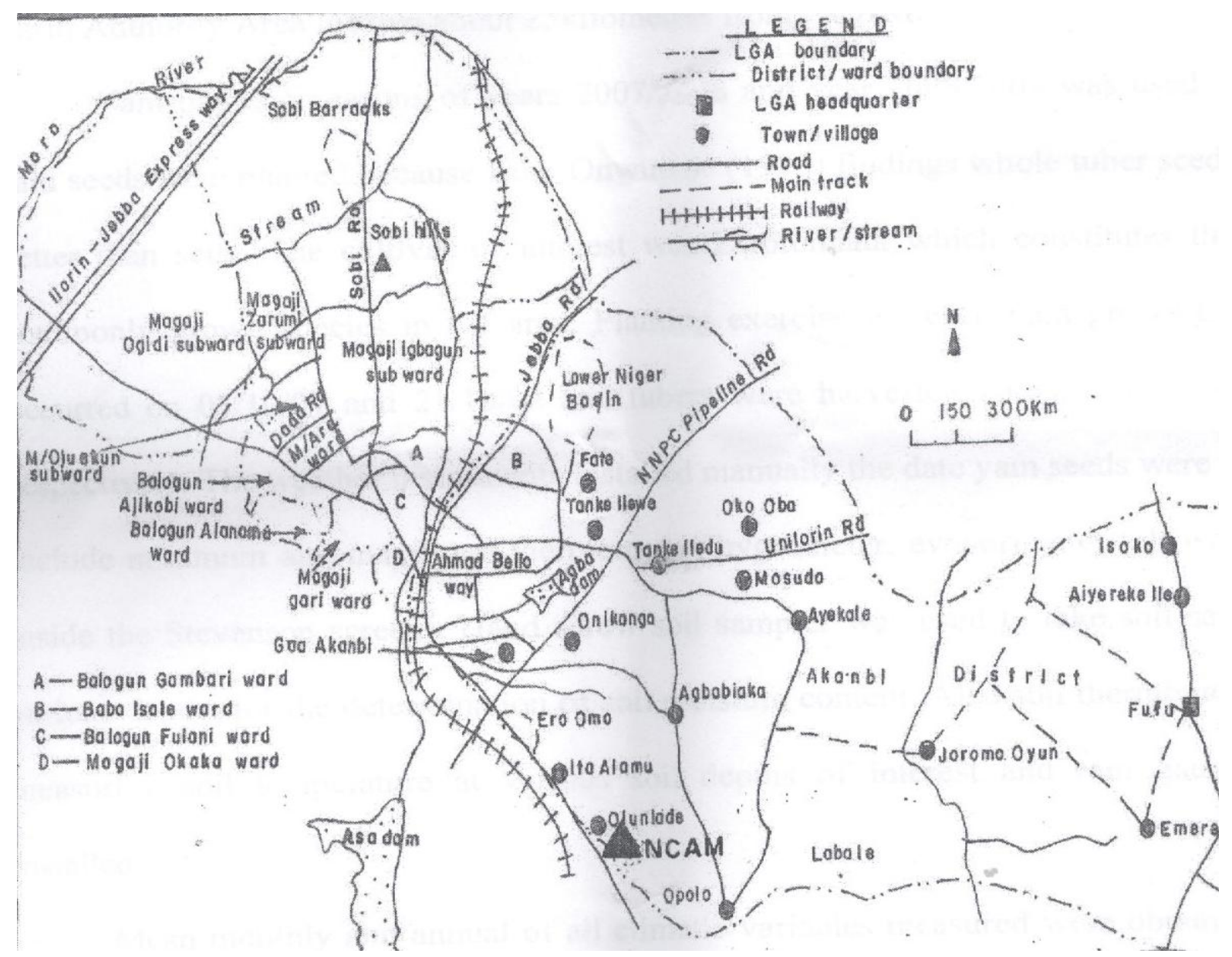

Figure 1. The map of ilorin south local government area showing NCAM the study area.

tices. Plot A was made up of 100 heaps prepared manually using hoe, B plot was ridged by tractor after harrowing while Plot $\mathrm{C}$ was only harrowed by tractor. The first two represent total tillage because the soil was deeply cultivated while Plot $C$ where the soil was not well worked constitutes a partial tillage system. All together there are 3 sampling plots from which data were generated. The experiment was conducted 2007 through 2009. All plots were sited upland for easy comparison. Soil sample were taken on weekly basis from these various soil depths intervals of $0-15 \mathrm{~cm}, 15-30 \mathrm{~cm}, 30-45 \mathrm{~cm}$ and $45-60 \mathrm{~cm}$ respectively using hand screw soil urger. Each sample was weighed and recorded. The percentage moisture was determined by oven drying soil samples to a constant weight at $105^{\circ} \mathrm{C}$ temperature. The difference between the initial weight and weight after oven drying was obtained and the percentage calculated.

The weekly data generated were grouped on monthly basis and the means for the period of study was calculated. Statistic tool of ANOVA was used to investigate the level of variations in soil moisture content between tillage systems at various depths and level of soil moisture variations between the two major seasons experienced in Nigeria. Dry season covers the period of November to April while rainy season starts in earnest in May and continues till October in the study area. Post HOC multiple comparison was carried out using Tukey test at 0.05 significant level to reveal which tillage method and what season is the soil moisture content different from the others.

\section{Result and Discussion}

Variations observed in soil moisture under different soil depth intervals among the three tillage system of mound, ridge and plough are presented and discussed under this session. 


\subsection{Variation in Soil Moisture among Tillage System}

When the distribution of soil moisture with depths among the three tillage systems was considered, some pattern was observed. Generally soil moisture increased with depth in all the three tillage systems (See Figures 2-4).

Variation in soil moisture was most pronounced between the depth intervals of $0-15$ and $15-30 \mathrm{~cm}$. After this depth interval the difference in soil moisture was not much.

\subsection{Variation in Soil Moisture at 0 - $15 \mathrm{~cm}$ Soil Depth Interval among Tillage Systems}

Variation in soil moisture within the soil depth interval of $0-15 \mathrm{~cm}$ among the three tillage system is reflected in Figure 5 (See also Table A1).

At this soil interval, ridge tillage system recorded the highest soil moisture from January through December. This is followed closely by plough except in the month of February and June when higher values of $0.85 \%$ and $17.70 \%$ were observed in mound tillage as against $0.78 \%$ and $15.86 \%$ reported for plough tillage. Thus mound tillage environment remained the driest of the three tillage systems at this soil interval.

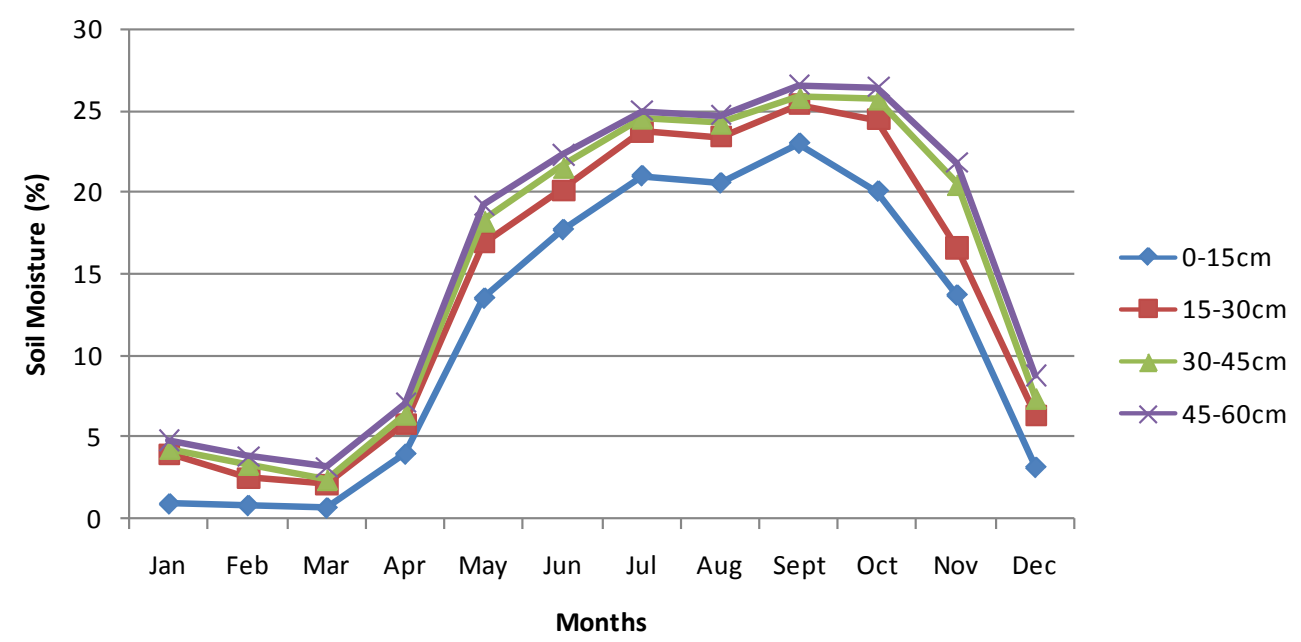

Figure 2. Variation in soil moisture at varying depth intervals in mound tillage system. Source: author's fieldwork 2014.

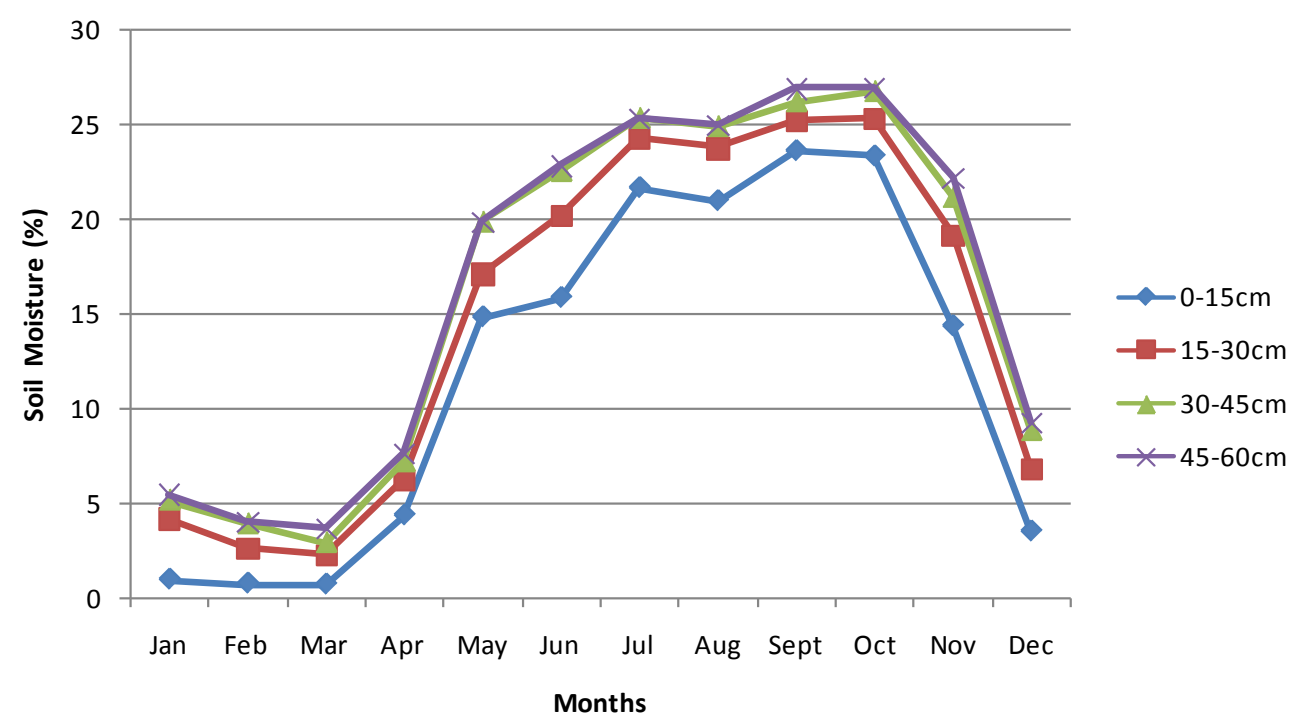

Figure 3. Variation in soil moisture at varying depth intervals in plough tillage system. Source: author's fieldwork 2014. 


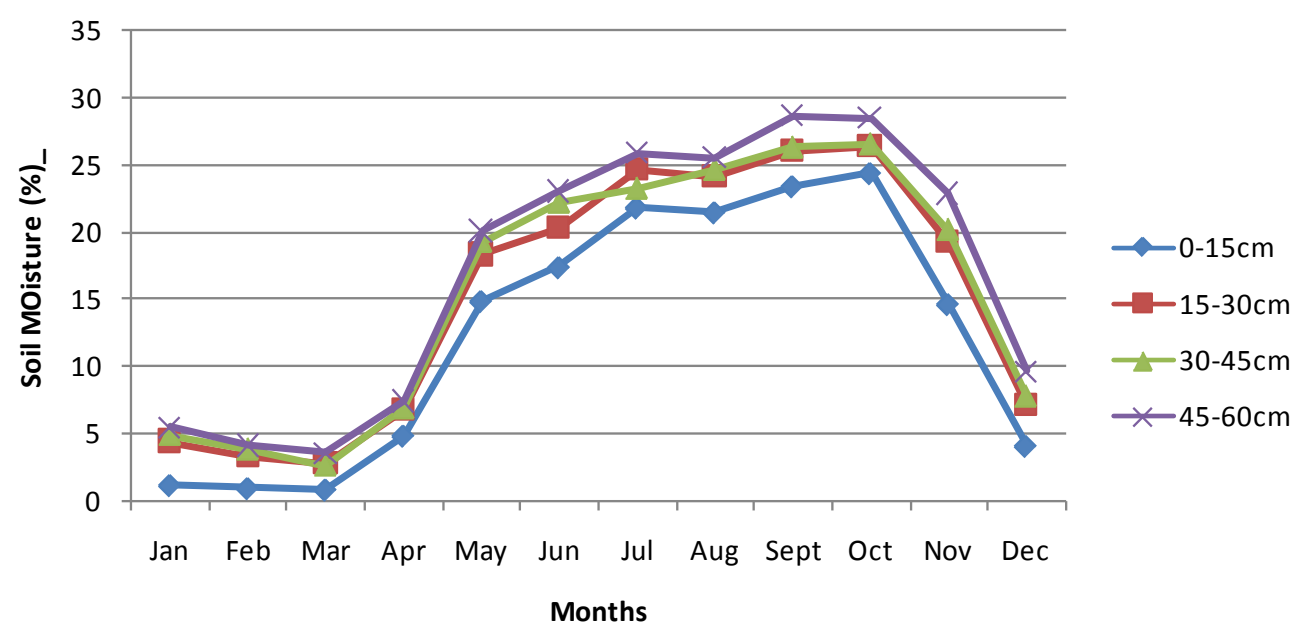

Figure 4. Variation in soil moisture at varying depth intervals in ridge tillage system. Source: author's fieldwork 2014.

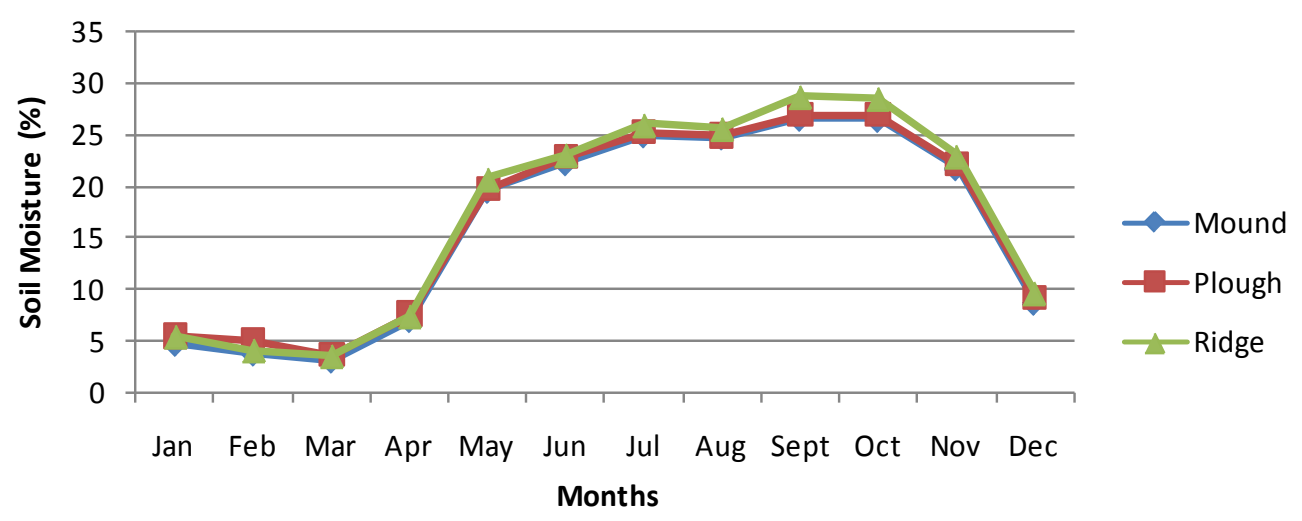

Figure 5. Variation in soil moisture at $0-15 \mathrm{~cm}$ soil depth interval among tillage systems. Source: author's fieldwork 2014.

\subsection{Variation at 15 - $30 \mathrm{~cm}$ Soil Depth Interval among Tillage Systems}

Figure 6 showed the variations in soil moisture that exist between the three tillage systems at soil depth interval of 15 - $30 \mathrm{~cm}$ (Also see Table A2).

The distribution of soil moisture at this soil depth interval resemble the pattern of distribution at $0-15 \mathrm{~cm}$ soil depth interval previously discussed above. The exception is that during the month of March, mound tillage recorded the highest percentage of soil moisture (2.20\%) as against $2.13 \%$ and $2.18 \%$ observed in plough and ridge tillage systems. Mound tillage still maintained the driest condition while ridge tillage retained its wettest position. Variation in soil moisture between mound tillage and others became very pronounced in the month of November that marked the beginning of dry season in the area.

\subsection{Variation at 30 - $45 \mathrm{~cm}$ Soil Depth Internal among Tillage Systems}

The distribution of soil moisture among the three tillage systems at the soil depth interval of $30 \mathrm{~cm}-45 \mathrm{~cm}$ is showed in Figure 7 (see also Table A3).

At the soil depth of $30-45 \mathrm{~cm}$, the pattern of variation in soil moisture among the three tillage systems changed. The plough tillage emerged the wettest as it observed the highest soil moisture content at this depth interval through the period under consideration. Mound tillage still observed the lowest percentage of soil moisture content. Highest Soil Moisture observed at this soil depth interval by plough tillage system might be attributable to the fact that the Soil of plough tillage is not well worked and it remained compacted thus slowing down the rate at which water infiltrates into the soil at the soil depth interval. 


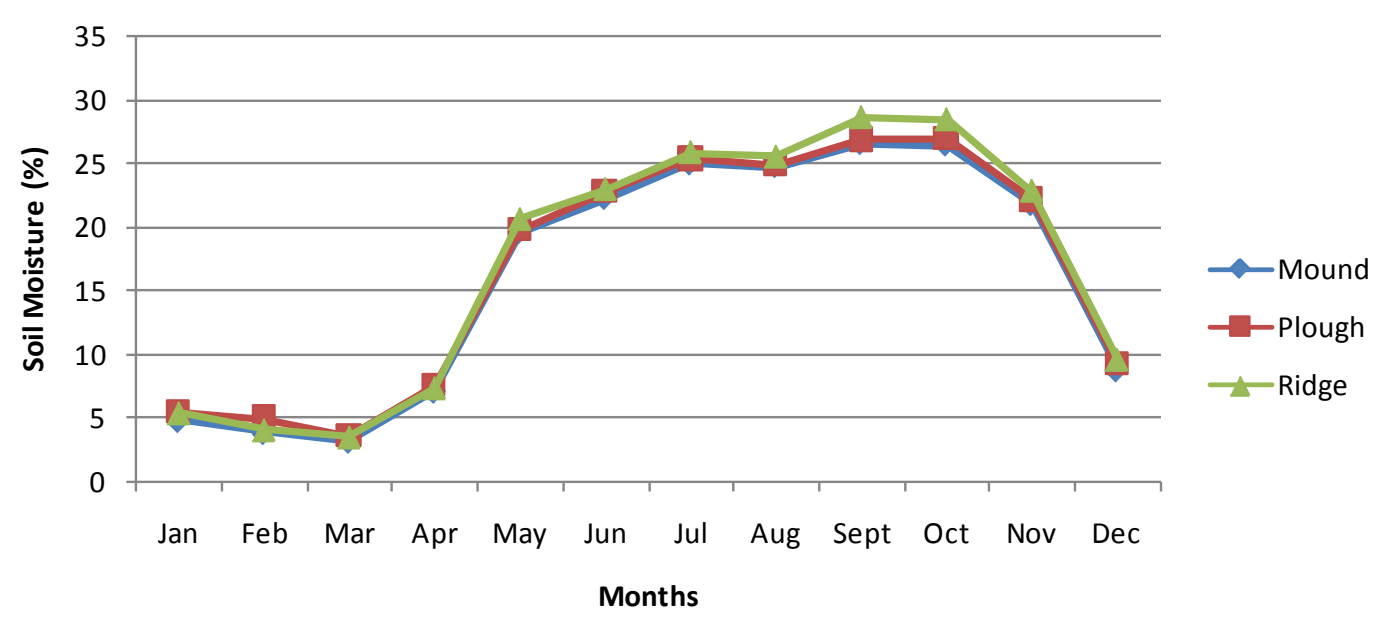

Figure 6. Variation in soil moisture at 0 - $15 \mathrm{~cm}$ soil depth interval among tillage systems Source: author's fieldwork 2014.

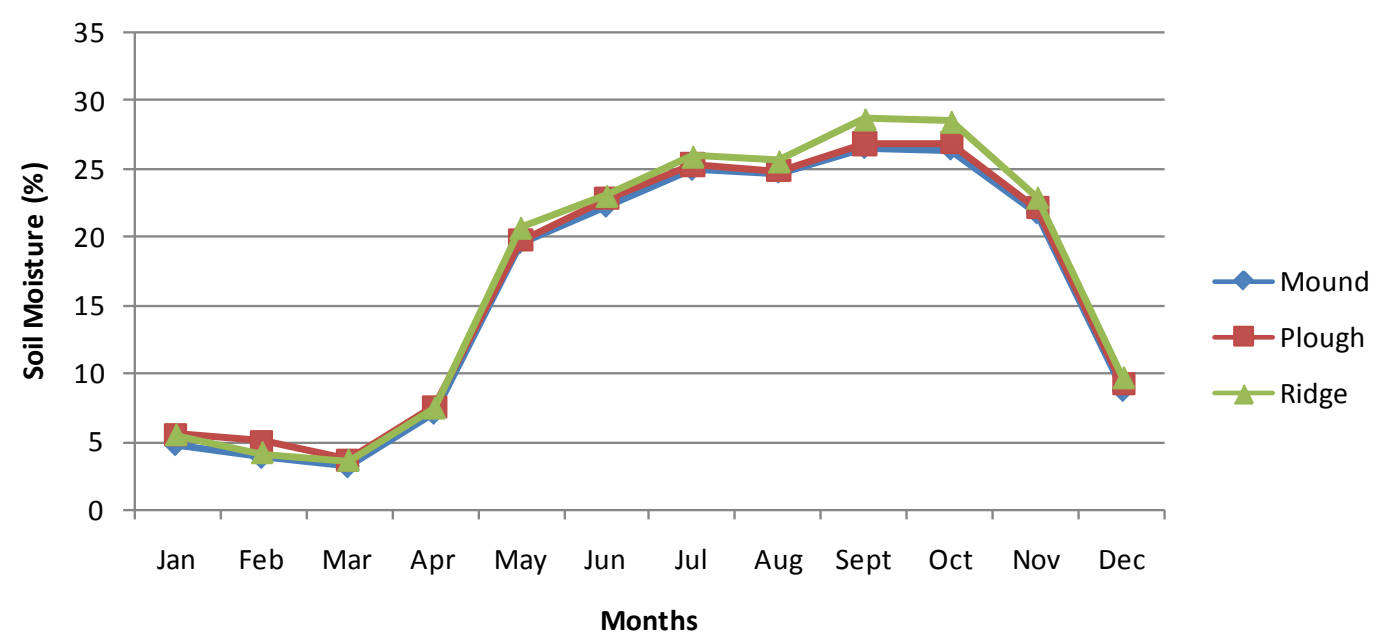

Figure 7. Variation in soil moisture at $0-15 \mathrm{~cm}$ soil depth interval among tillage systems. Source: author's fieldwork 2014.

\subsection{Variation in Soil Moisture at 45 - $60 \mathrm{~cm}$ Depth among Tillage Systems}

Figure 8 reflects the distribution of soil moisture at the soil depth intervals of $45-60 \mathrm{~cm}$. At this soil depth interval the initial pattern of soil moisture distribution among tillage systems was re-established.

Ridge tillage became the wettest followed by plough and mound tillage systems. The exception of this is the month of March and April when plough system still retained highest value of 3.68\% and 7.61\% (see Table A4).

The lowest soil moisture content observed in plot under mound tillage may not be unconnected with the findings of [11]. Heat circulates within each heap of the mound tillage thus raising its temperature but horizontal transfer of heat occur in ridge tillage and so cooler than mound tillage. The implication of this is that evaporation is higher in mound tillage hence lowest soil moisture was reported under this tillage system.

\subsection{Result of ANOVA and Post Hoc Multiple Comparisons}

The descriptive statistics of seasonal variation in soil moisture between three different tillage systems at 0 - 15 $\mathrm{cm}$ soil depth showed that ridge tillage method in wet season has the highest mean soil moisture content of 20.58\%. While mound tillage method in dry season has the lowest mean soil moisture content of $3.40 \%$.

ANOVA summary Table 1, reveals that the between group mean square (the variation explained by the model) is 452.543, and the within group mean square (the variation unexplained) is 19.948 . The F-ratio is 22.687 and the $\mathrm{p}$-value $<0.05$, this indicates that the seasonal variation in soil moisture between the three tillage method 
at $0-15 \mathrm{~cm}$ depth is statistically significant. The table reveals that at least soil moisture content of one of the tillage method is different from the others.

Table 2 reflects the result of ANOVA summary for wet and dry season soil moisture between $15-30 \mathrm{~cm}$ soil depths. The between groups mean square (the variation explained by the model) is 460.626 , and the within group mean square (the variation unexplained) is 22.928 . The F-ratio is 20.090 and the p-value $<0.05$, this indicates that the seasonal variation in soil moisture between the three tillage method at $15-30 \mathrm{~cm}$ depth is statistically significant. The table reveals that at least soil moisture content of one of the tillage method is different from the others.

ANOVA summary Table 3 reveals that the between groups mean square (the variation explained by the model) is 461.516, and the within group mean square (the variation unexplained) is 25.544 . The F-ratio is 18.067 and the p-value $<0.05$, this indicates that the seasonal variation in soil moisture between the three tillage method at $30-45 \mathrm{~cm}$ depth is statistically significant. The table reveals that at least soil moisture content of one of the tillage method is different from the others.

ANOVA summary as presented in Table 4 reveals that the between group mean square (the variation explained by the model) is 463.090 , and the within group mean square (the variation unexplained) is 29.057 . The

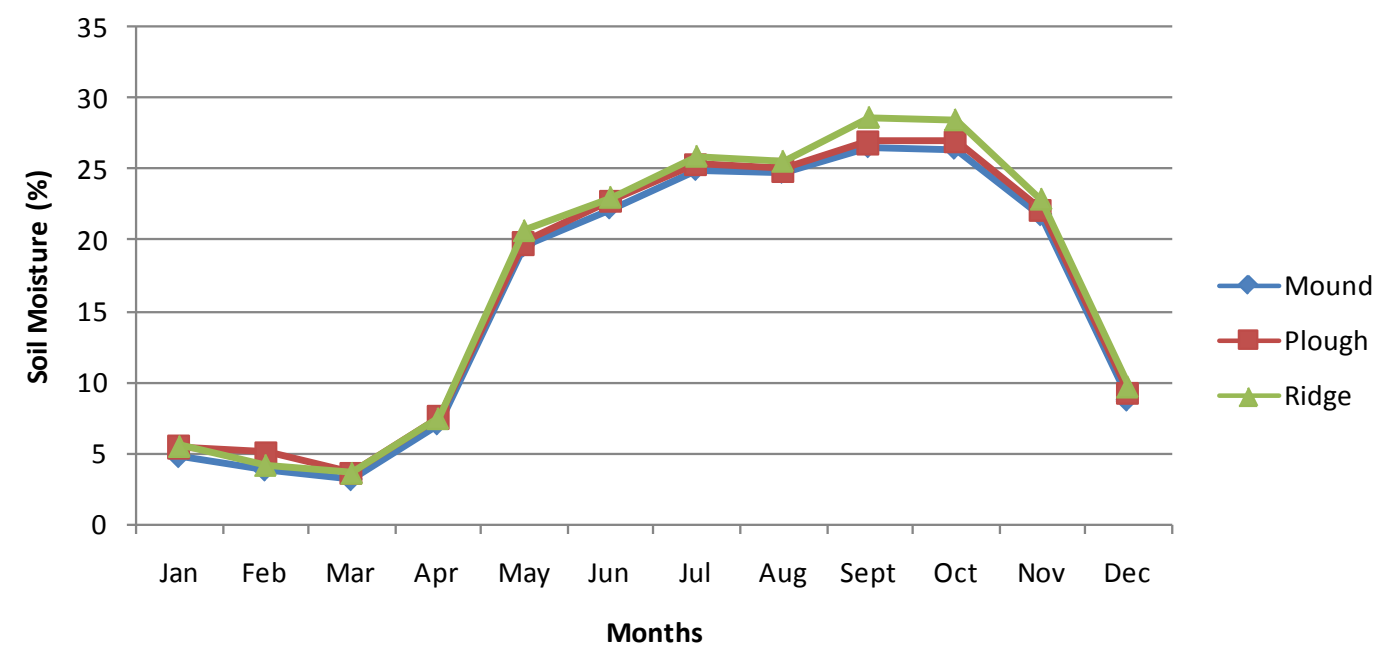

Figure 8. Variation in soil moisture at $0-15 \mathrm{~cm}$ soil depth interval among tillage systems. Source: author’s fieldwork 2014.

Table 1. ANOVA for wet and dry season soil moisture between $0-15 \mathrm{~cm}$.

\begin{tabular}{cccccc}
\hline Mound, Plough and Ridge & Sum of Squares & Df & Mean Square & F & Sig. \\
\hline Between Groups & 2262.716 & 5 & 452.543 & 22.687 & 0.000 \\
Within Groups & 598.428 & 30 & 19.948 & & \\
Total & 2861.144 & 35 & & \\
\hline
\end{tabular}

Source: author's computation 2014.

Table 2. ANOVA for wet and dry season soil moisture between $15-30 \mathrm{~cm}$.

\begin{tabular}{cccccc}
\hline Mound Plough Ridge & Sum of Squares & Df & Mean Square & F & Sig. \\
\hline Between Groups & 2303.128 & 5 & 460.626 & 20.090 & 0.000 \\
Within Groups & 867.853 & 30 & 22.928 & & \\
Total & 2990.981 & 35 & & \\
\hline
\end{tabular}

Source: author's computation 2014. 
Table 3. ANOVA for wet and dry season soil moisture between $30-45 \mathrm{~cm}$.

\begin{tabular}{cccccc}
\hline Mound Plough Ridge & Sum of Squares & Df & Mean Square & F & Sig. \\
\hline Between Groups & 2307.580 & 5 & 461.516 & 18.067 & 0.000 \\
Within Groups & 766.331 & 30 & 25.544 & & \\
Total & 3073.911 & 35 & & \\
\hline
\end{tabular}

Source: author's computation 2014.

Table 4. ANOVA for wet and dry season soil moisture between $45-60 \mathrm{~cm}$.

\begin{tabular}{cccccc} 
& Sum of Squares & Df & Mean Square & F & Sig \\
\hline Between Groups & 2315.449 & 5 & 463.090 & 15.937 & 0.000 \\
Within Groups & 871.706 & 30 & 29.057 & \\
Total & 3187.155 & 35 & & \\
\hline
\end{tabular}

Source: author's computation 2014.

F-ratio is 15.937 and the p-value $<0.05$, this indicates that the seasonal variation in soil moisture between the three tillage method at 45 - $60 \mathrm{~cm}$ depth is statistically significant. The table reveals that at least soil moisture content of one of the tillage method is different from the others.

Generally all the tables of ANOVA discussed however did not reveal which tillage method and what season is the soil moisture content is different from the others. To reveal this, Post Hoc multiple comparisons is carried out using Tukey test at 0.05 significant levels (see Tables A5-A8).

Variation in soil moisture content between the three tillage methods in wet season is not significant because the p-value $>$ than 0.05 . Also, the variation in soil moisture content between the three tillage methods in dry season is not significant because the p-value $>0.05$. However, statistically there is a difference in the seasonal variation in soil moisture content between the three tillage methods.

\section{Summary and Conclusion}

Mound tillage system remained the driest and ridge was the wettest at all depth intervals considered. The exception of this occurred at soil depth interval of $30-45 \mathrm{~cm}$ when plough tillage recorded highest value. Also the difference in soil moisture between varying depths was more pronounced between the soil depth intervals of 0 $15 \mathrm{~cm}$ and $15-30 \mathrm{~cm}$. In conclusion, further studies should examine the implications of the above findings on various crops produced in the Southern guinea savanna ecological zone of Nigeria. This calls for studying the root system of these crops and having adequate information on crop water requirement for effective planning, design, implementation and monitoring irrigation agriculture towards adequate food production in the Southern guinea eco zone of Nigeria.

\section{References}

[1] Nwajiuba, C. (2012) Does Agriculture Have a Future in Southeast Nigeria? Imo State University, Owerri.

[2] Ayoade, J.O. (2004) Introduction to Climatology for the Tropics. Ibadan Spectrum Books Limited.

[3] Wolkowski, D. (2014) Tillage Effect on Soil Moisture: Alberta Agriculture and Rural Development 2004-2014.

[4] Chukwu, G.O. and Madu, T.U. (2010) Crop Water Requirement: 29 Years’ Reseach at NRCRI Umudike in Climate Change and Nigeria Environment. In: Anyadike, R.N.C., Madu, I.A. and Ajaero, C.K., Eds., Climate Change and Nigeria Environment, Department of Geography University of Nsukka Conference Proceedings, 185-199.

[5] Pearson, K. (2014) How and When Does Water Stress Impact Plat Growth and Development? Montana State University, Bozeman.

[6] Lindwall, C.W. (1984) Minimizing Tillage Operations. Soil Conservation-Providing for the Future. Christian Farmers Federation, Lethbridge.

[7] Machelle, W. and Joel, G. (2008) Soil Management NRCS National Soil Survey, ARS National Laboratory Agriculture 
and Environment, NCERA-59 Scientists and Department of Natural Resources and Environmental Science, University of Ilinois.

[8] Saied, K.D. and Narob, M.C. (2013) The Effects of 4 Types of Tillage Operations on Soil Moisture and Morphology and Performance of 3 Varieties of Cotton. European Journal of Experimental Biology, 3, 694-698.

[9] Mackay, A.D. and Barber, S.A. (1985) Effect of Soil Moisture and Phosphate Level on Root Hair Growth of Corn Root. Journal of Plant and Soil, 86, 321-331. http://dx.doi.org/10.1007/BF02145453

[10] Shiwachi, H., Komoda, M. and Takahashi, H. (2008) Tillage Effect on Soil Moisture, Sress on the Growth of Corchorus olitorius L. African Journal of Agricultural Research, 4, 279-293.

[11] Odjugo, A.P. (2003) An Analysis of the Effectiveness of Traditional Techniques of on Farm Micro Climate Improvement in Mid-Western Nigeria. Unpublished Ph.D. Thesis, University of Ibadan, Ibadan. 


\section{Appendix}

Table A1. Seasonal variation in soil moisture at 0 - $15 \mathrm{~cm}$ soil depth interval (2007-2009).

\begin{tabular}{|c|c|c|c|c|c|c|c|c|c|c|c|c|}
\hline Tillage System & Jan & Feb & Mar & April & May & June & July & Aug & Sept & Oct & Nov & Dec \\
\hline Mound & 0.95 & 0.85 & 0.70 & 3.99 & 13.15 & 17.70 & 20.99 & 20.55 & 22.97 & 20.05 & 13.70 & 3.18 \\
\hline Plough & 0.99 & 0.78 & 0.73 & 4.38 & 14.84 & 15.86 & 21.66 & 20.97 & 23.61 & 23.33 & 14.37 & 3.53 \\
\hline Ridge & 1.12 & 0.89 & 0.78 & 4.81 & 14.86 & 17.39 & 21.85 & 21.49 & 23.44 & 24.42 & 14.64 & 4.05 \\
\hline
\end{tabular}

Table A2. Seasonal variation in soil moisture at 15 - $30 \mathrm{~cm}$ soil depths interval (2007-2009).

\begin{tabular}{|c|c|c|c|c|c|c|c|c|c|c|c|c|}
\hline Tillage System & Jan & Feb & Mar & April & May & June & July & Aug & Sept & Oct & Nov & Dec \\
\hline Mound & 4.04 & 2.56 & 2.20 & 5.91 & 16.96 & 20.17 & 23.77 & 23.45 & 25.39 & 24.45 & 16.62 & 6.44 \\
\hline Plough & 4.19 & 2.64 & 2.3 & 6.24 & 17.12 & 20.19 & 24.27 & 23.76 & 25.24 & 25.33 & 19.19 & 6.80 \\
\hline Ridge & 4.43 & 3.30 & 2.8 & 6.78 & 18.39 & 20.35 & 24.72 & 24.24 & 26.16 & 26.45 & 19.28 & 7.14 \\
\hline
\end{tabular}

Table A3. Seasonal variation in soil moisture at 30 - $45 \mathrm{~cm}$ soil depths interval (2007-2009).

\begin{tabular}{cccccccccccccc}
\hline Tillage System & Jan & Feb & Mar & April & May & June & July & Aug & Sept & Oct & Nov & Dec \\
Mound & 4.35 & 3.37 & 2.44 & 6.44 & 18.25 & 21.54 & 24.55 & 24.24 & 25.81 & 25.72 & 20.49 & 7.41 \\
& & & & & & & & & & & & & \\
Plough & 5.20 & 3.95 & 2.96 & 7.22 & 19.86 & 22.53 & 25.33 & 24.90 & 26.21 & 26.75 & 21.17 & 8.87 \\
Ridge & 4.92 & 3.82 & 2.68 & 6.89 & 19.31 & 22.23 & 23.27 & 24.68 & 26.33 & 26.58 & 20.20 & 7.77 \\
\hline
\end{tabular}

Table A4. Seasonal variation in soil moisture at 45 - $60 \mathrm{~cm}$ soil depth interval (2007-2009).

\begin{tabular}{|c|c|c|c|c|c|c|c|c|c|c|c|c|}
\hline Tillage System & Jan & Feb & Mar & April & May & June & July & Aug & Sept & Oct & Nov & Dec \\
\hline Mound & 4.80 & 3.86 & 3.18 & 7.10 & 19.60 & 22.27 & 24.97 & 24.77 & 26.57 & 26.46 & 21.79 & 8.77 \\
\hline Plough & 5.48 & 4.05 & 3.68 & 7.61 & 19.89 & 22.84 & 25.37 & 24.95 & 26.90 & 26.95 & 22.20 & 9.24 \\
\hline Ridge & 5.49 & 4.16 & 3.60 & 7.45 & 20.10 & 23.05 & 25.94 & 25.59 & 28.68 & 28.51 & 22.92 & 9.68 \\
\hline
\end{tabular}

Dry season Nov-April; Wet season May-Oct. 
Table A5. Multiple comparisons for soil moisture between 0 - $15 \mathrm{~cm}$ depth.

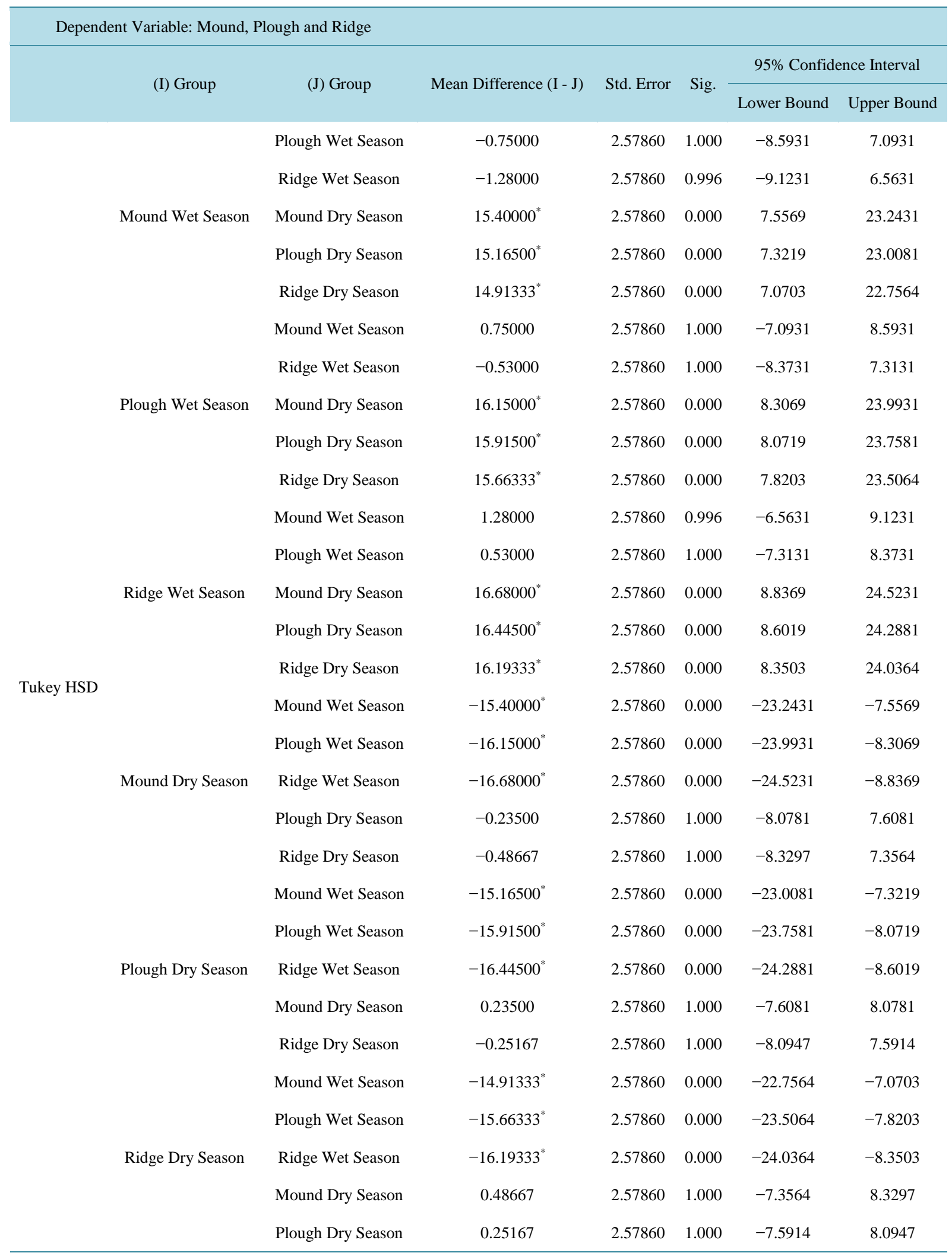

* The mean difference is significant at the 0.05 level. 
Table A6. Multiple comparisons for soil moisture between 15 - 30 cm depth.

\begin{tabular}{|c|c|c|c|c|c|c|}
\hline \multicolumn{7}{|l|}{ Tukey HSD } \\
\hline \multirow{2}{*}{ (I) Group } & \multirow{2}{*}{ (J) Group } & \multirow{2}{*}{ Mean Difference (I - J) } & \multirow{2}{*}{ Std. Error } & \multirow{2}{*}{ Sig. } & \multicolumn{2}{|c|}{ 95\% Confidence Interval } \\
\hline & & & & & Lower Bound & Upper Bound \\
\hline \multirow{5}{*}{ Mound Wet Season } & Plough Wet Season & -0.28667 & 2.76456 & 1.000 & -8.6953 & 8.1220 \\
\hline & Ridge Wet Season & -1.02000 & 2.76456 & 0.999 & -9.4287 & 7.3887 \\
\hline & Mound Dry Season & $16.07000^{*}$ & 2.76456 & 0.000 & 7.6613 & 24.4787 \\
\hline & Plough Dry Season & $15.47167^{*}$ & 2.76456 & 0.000 & 7.0630 & 23.8803 \\
\hline & Ridge Dry Season & $15.07667^{*}$ & 2.76456 & 0.000 & 6.6680 & 23.4853 \\
\hline \multirow{5}{*}{ Plough Wet Season } & Mound Wet Season & 0.28667 & 2.76456 & 1.000 & -8.1220 & 8.6953 \\
\hline & Ridge Wet Season & -0.73333 & 2.76456 & 1.000 & -9.1420 & 7.6753 \\
\hline & Mound Dry Season & $16.35667^{*}$ & 2.76456 & 0.000 & 7.9480 & 24.7653 \\
\hline & Plough Dry Season & $15.75833^{*}$ & 2.76456 & 0.000 & 7.3497 & 24.1670 \\
\hline & Ridge Dry Season & $15.36333^{*}$ & 2.76456 & 0.000 & 6.9547 & 23.7720 \\
\hline \multirow{5}{*}{ Ridge Wet Season } & Mound Wet Season & 1.02000 & 2.76456 & 0.999 & -7.3887 & 9.4287 \\
\hline & Plough Wet Season & 0.73333 & 2.76456 & 1.000 & -7.6753 & 9.1420 \\
\hline & Mound Dry Season & $17.09000^{*}$ & 2.76456 & 0.000 & 8.6813 & 25.4987 \\
\hline & Plough Dry Season & $16.49167^{*}$ & 2.76456 & 0.000 & 8.0830 & 24.9003 \\
\hline & Ridge Dry Season & $16.09667^{*}$ & 2.76456 & 0.000 & 7.6880 & 24.5053 \\
\hline \multirow{5}{*}{ Mound Dry Season } & Mound Wet Season & $-16.07000^{*}$ & 2.76456 & 0.000 & -24.4787 & -7.6613 \\
\hline & Plough Wet Season & $-16.35667^{*}$ & 2.76456 & 0.000 & -24.7653 & -7.9480 \\
\hline & Ridge Wet Season & $-17.09000^{*}$ & 2.76456 & 0.000 & -25.4987 & -8.6813 \\
\hline & Plough Dry Season & -0.59833 & 2.76456 & 1.000 & -9.0070 & 7.8103 \\
\hline & Ridge Dry Season & -0.99333 & 2.76456 & 0.999 & -9.4020 & 7.4153 \\
\hline \multirow{5}{*}{ Plough Dry Season } & Mound Wet Season & $-15.47167^{*}$ & 2.76456 & 0.000 & -23.8803 & -7.0630 \\
\hline & Plough Wet Season & $-15.75833^{*}$ & 2.76456 & 0.000 & -24.1670 & -7.3497 \\
\hline & Ridge Wet Season & $-16.49167^{*}$ & 2.76456 & 0.000 & -24.9003 & -8.0830 \\
\hline & Mound Dry Season & 0.59833 & 2.76456 & 1.000 & -7.8103 & 9.0070 \\
\hline & Ridge Dry Season & -0.39500 & 2.76456 & 1.000 & -8.8037 & 8.0137 \\
\hline \multirow{5}{*}{ Ridge Dry Season } & Mound Wet Season & $-15.07667^{*}$ & 2.76456 & 0.000 & -23.4853 & -6.6680 \\
\hline & Plough Wet Season & $-15.36333^{*}$ & 2.76456 & 0.000 & -23.7720 & -6.9547 \\
\hline & Ridge Wet Season & $-16.09667^{*}$ & 2.76456 & 0.000 & -24.5053 & -7.6880 \\
\hline & Mound Dry Season & 0.99333 & 2.76456 & 0.999 & -7.4153 & 9.4020 \\
\hline & Plough Dry Season & 0.39500 & 2.76456 & 1.000 & -8.0137 & 8.8037 \\
\hline
\end{tabular}

*The mean difference is significant at the 0.05 level. 
Table A7. Multiple comparisons for soil moisture between 30 - 45 cm depth.

\begin{tabular}{|c|c|c|c|c|c|c|}
\hline Tukey HSD & & & & & & \\
\hline \multirow{2}{*}{ (I) Group } & \multirow{2}{*}{ (J) Group } & \multirow{2}{*}{ Mean Difference (I - J) } & \multirow{2}{*}{ Std. Error } & \multirow{2}{*}{ Sig. } & \multicolumn{2}{|c|}{ 95\% Confidence Interval } \\
\hline & & & & & Lower Bound & Upper Bound \\
\hline \multirow{5}{*}{ Mound Wet Season } & Plough Wet Season & -0.91167 & 2.91801 & 1.000 & -9.7871 & 7.9637 \\
\hline & Ridge Wet Season & -0.38167 & 2.91801 & 1.000 & -9.2571 & 8.4937 \\
\hline & Mound Dry Season & $15.93500^{*}$ & 2.91801 & 0.000 & 7.0596 & 24.8104 \\
\hline & Plough Dry Season & $15.12333^{*}$ & 2.91801 & 0.000 & 6.2479 & 23.9987 \\
\hline & Ridge Dry Season & $15.63833^{*}$ & 2.91801 & 0.000 & 6.7629 & 24.5137 \\
\hline \multirow{5}{*}{ Plough Wet Season } & Mound Wet Season & 0.91167 & 2.91801 & 1.000 & -7.9637 & 9.7871 \\
\hline & Ridge Wet Season & 0.53000 & 2.91801 & 1.000 & -8.3454 & 9.4054 \\
\hline & Mound Dry Season & $16.84667^{*}$ & 2.91801 & 0.000 & 7.9713 & 25.7221 \\
\hline & Plough Dry Season & $16.03500^{*}$ & 2.91801 & 0.000 & 7.1596 & 24.9104 \\
\hline & Ridge Dry Season & $16.55000^{*}$ & 2.91801 & 0.000 & 7.6746 & 25.4254 \\
\hline \multirow{5}{*}{ Ridge Wet Season } & Mound Wet Season & 0.38167 & 2.91801 & 1.000 & -8.4937 & 9.2571 \\
\hline & Plough Wet Season & -0.53000 & 2.91801 & 1.000 & -9.4054 & 8.3454 \\
\hline & Mound Dry Season & $16.31667^{*}$ & 2.91801 & 0.000 & 7.4413 & 25.1921 \\
\hline & Plough Dry Season & $15.50500^{*}$ & 2.91801 & 0.000 & 6.6296 & 24.3804 \\
\hline & Ridge Dry Season & $16.02000^{*}$ & 2.91801 & 0.000 & 7.1446 & 24.8954 \\
\hline \multirow{5}{*}{ Mound Dry Season } & Mound Wet Season & $-15.93500^{*}$ & 2.91801 & 0.000 & -24.8104 & -7.0596 \\
\hline & Plough Wet Season & $-16.84667^{*}$ & 2.91801 & 0.000 & -25.7221 & -7.9713 \\
\hline & Ridge Wet Season & $-16.31667^{*}$ & 2.91801 & 0.000 & -25.1921 & -7.4413 \\
\hline & Plough Dry Season & -0.81167 & 2.91801 & 1.000 & -9.6871 & 8.0637 \\
\hline & Ridge Dry Season & -0.29667 & 2.91801 & 1.000 & -9.1721 & 8.5787 \\
\hline \multirow{5}{*}{ Plough Dry Season } & Mound Wet Season & $-15.12333^{*}$ & 2.91801 & 0.000 & -23.9987 & -6.2479 \\
\hline & Plough Wet Season & $-16.03500^{*}$ & 2.91801 & 0.000 & -24.9104 & -7.1596 \\
\hline & Ridge Wet Season & $-15.50500^{*}$ & 2.91801 & 0.000 & -24.3804 & -6.6296 \\
\hline & Mound Dry Season & 0.81167 & 2.91801 & 1.000 & -8.0637 & 9.6871 \\
\hline & Ridge Dry Season & 0.51500 & 2.91801 & 1.000 & -8.3604 & 9.3904 \\
\hline \multirow{5}{*}{ Ridge Dry Season } & Mound Wet Season & $-15.63833^{*}$ & 2.91801 & 0.000 & -24.5137 & -6.7629 \\
\hline & Plough Wet Season & $-16.55000^{*}$ & 2.91801 & 0.000 & -25.4254 & -7.6746 \\
\hline & Ridge Wet Season & $-16.02000^{*}$ & 2.91801 & 0.000 & -24.8954 & -7.1446 \\
\hline & Mound Dry Season & 0.29667 & 2.91801 & 1.000 & -8.5787 & 9.1721 \\
\hline & Plough Dry Season & -0.51500 & 2.91801 & 1.000 & -9.3904 & 8.3604 \\
\hline
\end{tabular}

*The mean difference is significant at the 0.05 level. 
Table A8. Multiple comparisons for soil moisture between 45 - 60 cm depth.

\begin{tabular}{|c|c|c|c|c|c|c|}
\hline \multicolumn{7}{|l|}{ Tukey HSD } \\
\hline \multirow{2}{*}{ (I) Group } & \multirow{2}{*}{ (J) Group } & \multirow{2}{*}{ Mean Difference (I - J) } & \multirow{2}{*}{ Std. Error } & \multirow{2}{*}{ Sig. } & \multicolumn{2}{|c|}{ 95\% Confidence Interval } \\
\hline & & & & & Lower Bound & Upper Bound \\
\hline \multirow{5}{*}{ Mound Wet Season } & Plough Wet Season & -0.37667 & 3.11217 & 1.000 & -9.8426 & 9.0893 \\
\hline & Ridge Wet Season & -1.20500 & 3.11217 & 0.999 & -10.6710 & 8.2610 \\
\hline & Mound Dry Season & $15.85667^{*}$ & 3.11217 & 0.000 & 6.3907 & 25.3226 \\
\hline & Plough Dry Season & $15.39667^{*}$ & 3.11217 & 0.000 & 5.9307 & 24.8626 \\
\hline & Ridge Dry Season & $15.22333^{*}$ & 3.11217 & 0.000 & 5.7574 & 24.6893 \\
\hline \multirow{5}{*}{ Plough Wet Season } & Mound Wet Season & 0.37667 & 3.11217 & 1.000 & -9.0893 & 9.8426 \\
\hline & Ridge Wet Season & -0.82833 & 3.11217 & 1.000 & -10.2943 & 8.6376 \\
\hline & Mound Dry Season & $16.23333^{*}$ & 3.11217 & 0.000 & 6.7674 & 25.6993 \\
\hline & Plough Dry Season & $15.77333^{*}$ & 3.11217 & 0.000 & 6.3074 & 25.2393 \\
\hline & Ridge Dry Season & $15.60000^{*}$ & 3.11217 & 0.000 & 6.1340 & 25.0660 \\
\hline \multirow{5}{*}{ Ridge Wet Season } & Mound Wet Season & 1.20500 & 3.11217 & 0.999 & -8.2610 & 10.6710 \\
\hline & Plough Wet Season & 0.82833 & 3.11217 & 1.000 & -8.6376 & 10.2943 \\
\hline & Mound Dry Season & $17.06167^{*}$ & 3.11217 & 0.000 & 7.5957 & 26.5276 \\
\hline & Plough Dry Season & $16.60167^{*}$ & 3.11217 & 0.000 & 7.1357 & 26.0676 \\
\hline & Ridge Dry Season & $16.42833^{*}$ & 3.11217 & 0.000 & 6.9624 & 25.8943 \\
\hline \multirow{5}{*}{ Mound Dry Season } & Mound Wet Season & $-15.85667^{*}$ & 3.11217 & 0.000 & -25.3226 & -6.3907 \\
\hline & Plough Wet Season & $-16.23333^{*}$ & 3.11217 & 0.000 & -25.6993 & -6.7674 \\
\hline & Ridge Wet Season & $-17.06167^{*}$ & 3.11217 & 0.000 & -26.5276 & -7.5957 \\
\hline & Plough Dry Season & -0.46000 & 3.11217 & 1.000 & -9.9260 & 9.0060 \\
\hline & Ridge Dry Season & -0.63333 & 3.11217 & 1.000 & -10.0993 & 8.8326 \\
\hline \multirow{5}{*}{ Plough Dry Season } & Mound Wet Season & $-15.39667^{*}$ & 3.11217 & 0.000 & -24.8626 & -5.9307 \\
\hline & Plough Wet Season & $-15.77333^{*}$ & 3.11217 & 0.000 & -25.2393 & -6.3074 \\
\hline & Ridge Wet Season & $-16.60167^{*}$ & 3.11217 & 0.000 & -26.0676 & -7.1357 \\
\hline & Mound Dry Season & 0.46000 & 3.11217 & 1.000 & -9.0060 & 9.9260 \\
\hline & Ridge Dry Season & -0.17333 & 3.11217 & 1.000 & -9.6393 & 9.2926 \\
\hline \multirow{5}{*}{ Ridge Dry Season } & Mound Wet Season & $-15.22333^{*}$ & 3.11217 & 0.000 & -24.6893 & -5.7574 \\
\hline & Plough Wet Season & $-15.60000^{*}$ & 3.11217 & 0.000 & -25.0660 & -6.1340 \\
\hline & Ridge Wet Season & $-16.42833^{*}$ & 3.11217 & 0.000 & -25.8943 & -6.9624 \\
\hline & Mound Dry Season & 0.63333 & 3.11217 & 1.000 & -8.8326 & 10.0993 \\
\hline & Plough Dry Season & 0.17333 & 3.11217 & 1.000 & -9.2926 & 9.6393 \\
\hline
\end{tabular}

*The mean difference is significant at the 0.05 level. 
Scientific Research Publishing (SCIRP) is one of the largest Open Access journal publishers. It is currently publishing more than 200 open access, online, peer-reviewed journals covering a wide range of academic disciplines. SCIRP serves the worldwide academic communities and contributes to the progress and application of science with its publication.

Other selected journals from SCIRP are listed as below. Submit your manuscript to us via either submit@scirp.org or Online Submission Portal.
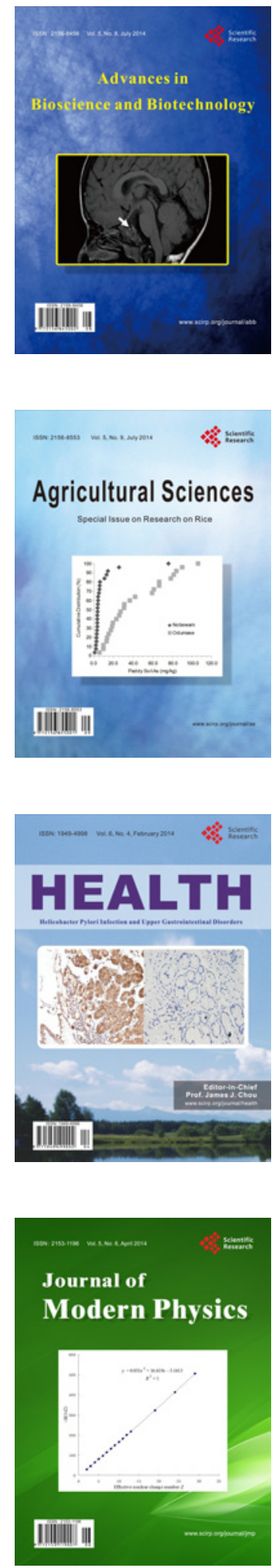
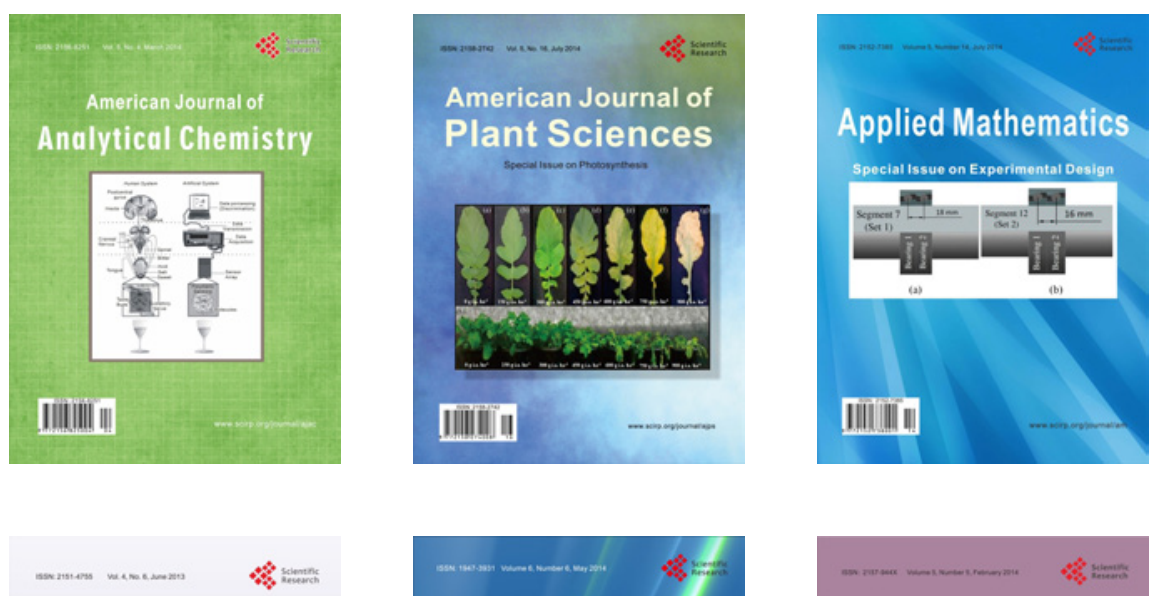

Creative Education
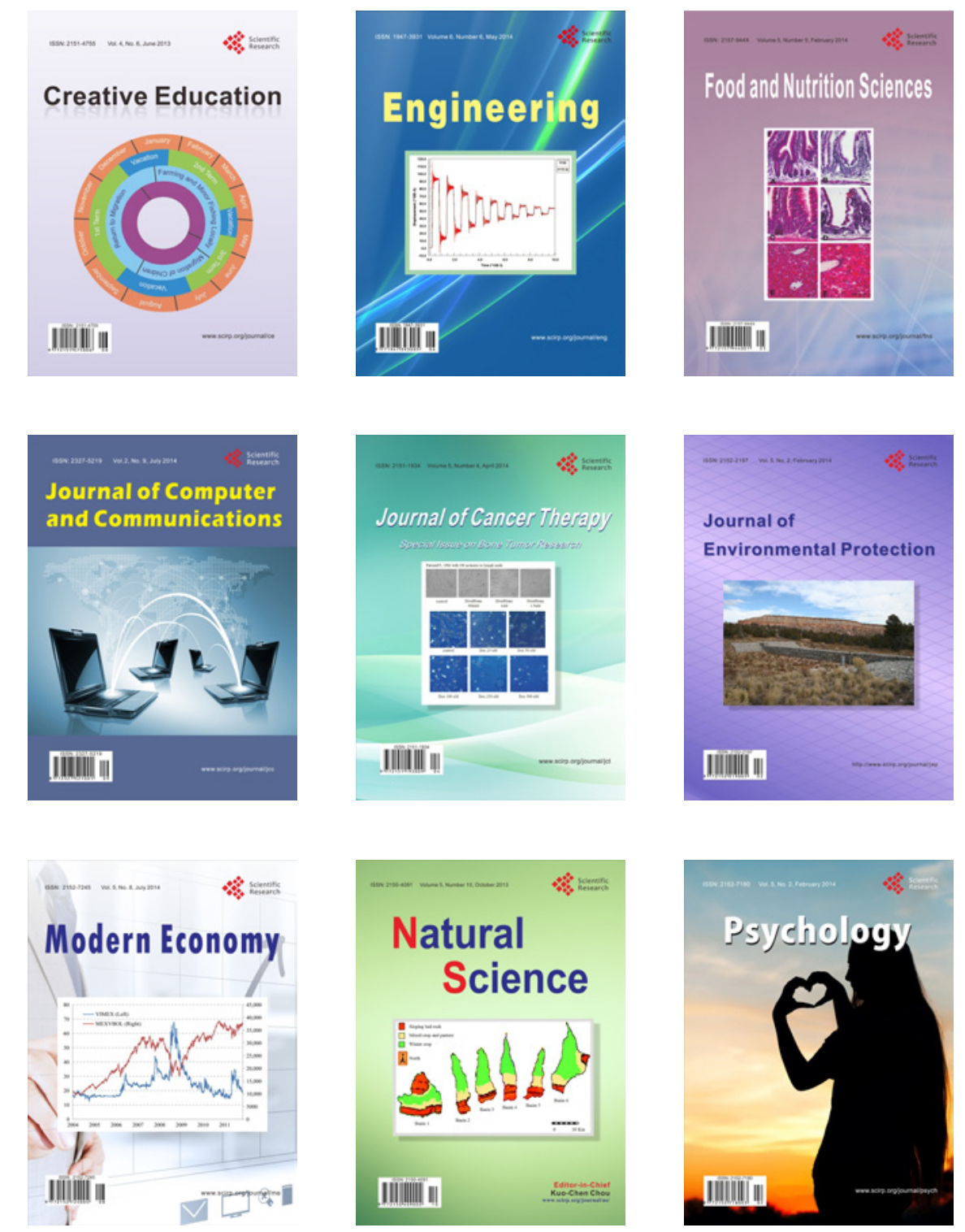